found the massive laterite basement of a stupa and a small stone inscribed with a Buddhist formula in a South Indian script, not later than the second half of the fourth century. Another stupa site to the south on the Bujang stream produced a sun-dried clay tablet, inscribed with three stanzas of a Mahayana text in Sanskrit, which previously was known only in Chinese. This antedates previous evidence from Sumatra of the introduction of Mahayana Buddhism into Indonesia by more than a hundred years.

Excavatios of mounds on the site of the ancient city of Lankasuka revealed remains of Shiva temples and established the Pallava affinities of the art of the colonists in the seventh and eighth centuries, while foundation deposits from temples excavated on Kedah peak consisted of caskets, which, though undoubtedly Indian in character, are of a type unknown in India and are explicable only by reference to Java. The ruined state of the temple buildings made it possible to excavate the foundations more thoroughly than is usually possible, with the result that much valuable information as to dating and cultural relations with southern India was obtained from this source. Especially noteworthy is evidence of a revival of Hinduism in the eleventh to fourteenth centuries. These results, as well as those of earlier expeditions of the Greater India Research Committee, for which Dr. Wales has been responsible, suggest that the criticisms directed against the projected exhibition of the art of Greater India (see Nature, July 1, p. 20) are outweighed by the advantages which will accrue to Indian cultural studies from the enhanced knowledge and interest in the art and archæology of Greater India which such an exhibition must arouse. This should result in stimulating further exploration and research. By tracing and exemplifying local developments of Buddhistic and Hindu art, the exhibition should in itself supply the unifying link, of which the absence has been imputed as one of the gravest defects of the proposal.

\section{Civil Defence}

Tne second Bulletin of the Air Raid Defence League gives an outline of civil defence in which the general framework is reviewed as a whole, so that the various technical, social and economic problems fall into their proper prospective in the defence of the whole living organism of a nation in a war zono. After discussing the nature and object of air attack and the policies which might be used by the attacker, the Bulletin concludes that evacuation of the congested target areas is the most radical strategic move and is called for on a much wider scale than is at present announced by the Government. It is urged that all who can should be evacuated and only special classes should stay. Careful planning of evacuation and action before war is in being could vastly reduce the dislocation caused by evacuation. A priority scheme, howover, is required as the basis of defence measures in which the proportionate risk has been roughly calculated on scientific principles. Bombproof accessible shelter both for work and for rest is advocated for those whose duty it will be to remain at work in the congested target areas and for the protection of those engaged in running vital services such as telephones or first aid. For less congested and vulnerable areas shallow shelters of the Anderson or other types or strengthened basements must be provided, and small communal shelters or strength. ened basements for large blocks of flats or offices are necessary.

TuE apathy of local authorities and the lack of staff for effective training are criticized as the chief hindrances to the effective utilization of volun. teers in national service. The Bulletin then urges the importance of policy being designed to make the economic system of Great Britain strategically less vulnerable. The Government should give a clear lead to industry to organize itself to meet war conditions and to undertake the preparation of suitable alternative premises and services of supply and to provide pools of reserve plant. Similarly the maintenance of food supply is of paramount importance. Reserve stocks of food must be accumulated and protected. Facilities for handling and storing food and essential commodities at ports at present little used but likely to be important in time of war in view of their com. parative safety should be improved. Much of our present storage is in highly vulnerable positions; so production of food should be greatly increased. Special stress is also laid upon the mobilization of science, the full resources of which are insufficiently utilized by the Government. Among subjects for urgent team research methods are food and storage, optical instruments, special drugs and shelter problems. The importance of full publicity is emphasized and establishment of a Ministry of Information is recommended.

\section{Earthquakes in California}

Ox the morning of June 23, an earthquake of considerable intensity was felt along the whole of the coast of Southern California. It was particularly severo at Hollister and Salina, where it was said to be the worst since 1906, though no material damage was done. California is particularly prone to local earthquakes and tremors, and a glance at the geomorphic map prepared by the Earthquake Investigation Commission shows that considerable movement has taken place from time to time along the great fault systems which chiefly run parallel with the coast line. In this particular instance it is difficult to state exactly where the epicentre may have been, but it is possible that slipping may have taken place along the San Andreas Fault which runs practically along the whole length of the affected area and lies approximately midway between Hollister and Salina. A second shock was felt at Pasadena and San Diego in the early afternoon of the same day. This probably had its epicentre in the moun. tainous region of Nevada ; it was sufficiently intense to have caused considerable damage had it occurred in a densely populated region. California has several seismological observatories, so that thorough investi- 